\title{
Potential of institutional arrangements for sustainable management of forests under co-management with local forest organisations in Mua-Livulezi Forest Reserve, Mtakataka, Malawi
}

\author{
T.C. SENGANIMALUNJE ${ }^{1,2 *}$, P.W. CHIRWA ${ }^{2}$ and F.D. BABALOLA ${ }^{2,3}$ \\ ${ }^{1}$ Malawi College of Forestry and Wildlife, Private Bag 6, Dedza, Malawi \\ ${ }^{2}$ Forest Science Postgraduate Programme, 5-15 Plant Sciences Complex, Faculty of Natural \\ and Agricultural Sciences, University of Pretoria, Hatfield, Pretoria 0028, South Africa \\ ${ }^{3}$ Department of Forest Resources Management, University of Ilorin, P.M.B 1515, Ilorin, Kwara \\ State, Nigeria.
}

Email: tchimsengani@gmail.com, paxie.chirwa@up.ac.za and folababs2000@yahoo.com

\begin{abstract}
Adoption of participatory forest management has initiated the trend of transfer of access, management and control of forest resources from government to committee based institutions. Hence, understanding the institutional arrangements that support implementation of comanagement with Local Forest Organisations is crucial for sustainable forest management. This study therefore examined the potential and contribution of institutional arrangements to sustainable forest management under co-management arrangement in Mtakataka, Malawi. Our results show that while co-management has created new multi-level local forest organizations in the communities, the potential of the organizations to contribute to sustainable forest management has been negatively affected by lack of appropriate power and legitimacy. There are clear and well defined boundaries for the forest resources and communities involved in comanagement of the forest reserve. However, co-management is faced with issues such as low participation of community members, ineffective rule enforcement, inadequate human and financial resources, and conflict of forest use. Despite these issues, it is concluded that with improvement in the co-management program, the local forest organisations have potential to achieve sustainable management of forest resources. It is thus recommended that the LFOs should be encouraged to follow what was jointly agreed upon and documented in the management plans. The management plans should also be regularly evaluated and effectively monitored for sustainable management and use of the forest products.
\end{abstract}

Key words: institutional arrangements, co-management, local forest organizations, sustainable forest management, Malawi.

\section{INTRODUCTION}

Over the last two decades, policy reforms leading towards more participatory forest governance have been initiated (Andersson 2006, Thin and Gardingen 2004). Access, as well as management and control of forest resources has followed the trend of traditional systems of leadership to government control and then to the current system of committee based institutions (Kellert et al. 
2000). This transfer of authority from government agencies to local level organizations (devolution) transfers control over resource management decision making, accommodates local interests and needs, and empowers users to benefit from and influence policy outcomes (Shackleton et al., 2002, Scherr et al., 2001). Participatory forestry emerged in the late 1980s as a strategy to encourage conservation and sustainable management of forest resources, and in recognition of rights of local communities to participate in the same (Arnold 2001, UNEP, 1992, SADC, 2002). Schrekenberg et al. (2006) defines participatory forestry management (PFM) as a term that refers to a wide range of activities that represent a new set of relationships between the state (usually forest departments) and communities in and adjacent to forests and woodlands. These activities include community forestry, co-management or joint forestry management (JFM) and community based natural resource management (CBNRM). PFM, due to its direct engagement with local communities, has been assumed to be an obvious way to achieve poverty reduction (Schrekenberg et al., 2006). However, it can lead to a 'poverty trap' in circumstances where forests do not provide enough returns to invest in livelihood improvement (Arnold, 2001). PFM initiatives (especially donor driven), therefore, should be mainstreamed within national and local government institutions so that they are more responsive to local situations, less costly and can be applied under different conditions (Thin and Gardingen, 2003; Blomley and Ramadhani, 2006, Matose, 2008).

Common property resource (CPR) management is being promoted as one way of achieving the transfer of some responsibility and authority over natural resources to communities, building on the potential of local institutions to effectively govern the natural resources such as forests (Campbell and Shackleton, 2001, Kayambazinthu et al. 2003). The success of the devolved management is dependent on the rural communities creating and sustaining the local institutions through popular participation in local decision making (Ostrom, et al. 1994, Paudel et al. 2010). Governments have a key facilitative role in building technical capacity and empowerment of forest users (Agrawal and Gupta 2005, Andersson 2006). The institutions developed, devise rules and regulations that ensure sustainable livelihoods through access to resources and markets (Ballabh et al. 2002, Kemp-Benedict et al. 2009, Swallow and Bromley 1995). However, there have been mixed outcomes on effectiveness of local institutions. For example, in Tanzania, degraded and overused woodlands were regenerated with enforcement of rules, while in Malawi regulation of use and users has been associated with both success and failure (Campbell et al., 2003). Collapse of local institutions has been attributed to lack of enabling environment; unsustainable exploitation of the resource; heterogeneity among households; lack of legitimate local institutions and resource characteristics (Campbell et al. 2003). On the other hand, Kayambazinthu et al. (2003) indicated that institutions that are based on tradition and culture are given legitimacy at local level and therefore more stable and lasting. There is however, a broad unanimity in modern-day literature on the factors that influence better performance of CPR institutions, basically the embodiment of sustainable participatory and/or adaptive forest resource management (Agrawal 2001, Baland and Platteau 1996, Ostrom 1990, Wade 1998). To address the study objectives, the Institutional Analysis and Development (IAD) framework (Andersson, 2006, Ostrom et al. 1994) was used to identify and explain the performance of local forest organizations, and the rules in use. The IAD framework allows analysis of 'institutional settings' in situations where people interact and follow rules (Symajgl et al., 2009).

Implementation of co-management in Malawi, using a collective action approach, was scaled up through an European Union funded government program, the Improved Forestry program for sustainable livelihoods program (IFMSLP). The program targeted twelve forest 
areas across Malawi as focus areas for implementation of the program activities. In addition to community mobilisation, the program facilitated development of strategic forest area plan for the selected forest areas, and management plans for forest blocks assigned to communities, and forest areas on customary lands. This process culminated into signing of the co-management agreement between government (represented by department of forestry) and the communities (represented by a local forest organisation) adjacent to the forest area.

The study tested the hypothesis that 'the performance of local institutions determines the potential of co-management to achieve sustainable forest management'. Therefore, the purpose of the study was two-fold: firstly, to examine the institutional framework for implementation of co-management in Mua-Livulezi forest reserve focusing on forest resource and user attributes, institutional arrangements and external environment. This purpose was addressed by answering the questions: (i) What is the existence of and membership in local forest organisations and (ii) How effective is the performance of the LFOs in accordance with set roles and responsibilities in co-management agreements? Specifically, the study looked at the extent at which the LFOs have met the institutional design principles and their effectiveness in fulfilling their obligations as set by the co-management agreement. Secondly the study examined the rules governing the use of forest resources. The questions asked were: (i) what conditions are in place for local forest organizations to successfully manage communally owned forest resources? And (ii) what rules are in place to regulate forest access and what is the perception of the people regarding the process of issuing permits? Specifically, the study examined forest access (forest areas and users), existence of access rules, process of issuance of permits, and perception of the change in the process and its implication.

\section{METHODOLOGY}

\section{Study Area}

The research was carried out in Dedza District (figure 1), one of the twelve target Districts of the Improved Forest Management for Sustainable Livelihood Program (IFMSLP) in Malawi. The total population for the District was estimated at 625, 828 (NSO, 2008) with a population density of 172 people per square $\mathrm{km}$, which is higher than the national average of 139 people per square $\mathrm{km}$. The District is divided into three topographic zones: the Lilongwe Plains, Dedza Highlands, and the Escarpments. The Lilongwe Plains are in the northern parts of the District and lie at an altitude of 1100-1300m above sea level. The Dedza Highlands (Kirk Range and Dzalanyama Range) occupy the western part while the escarpment occupy the eastern part of Dedza District. 


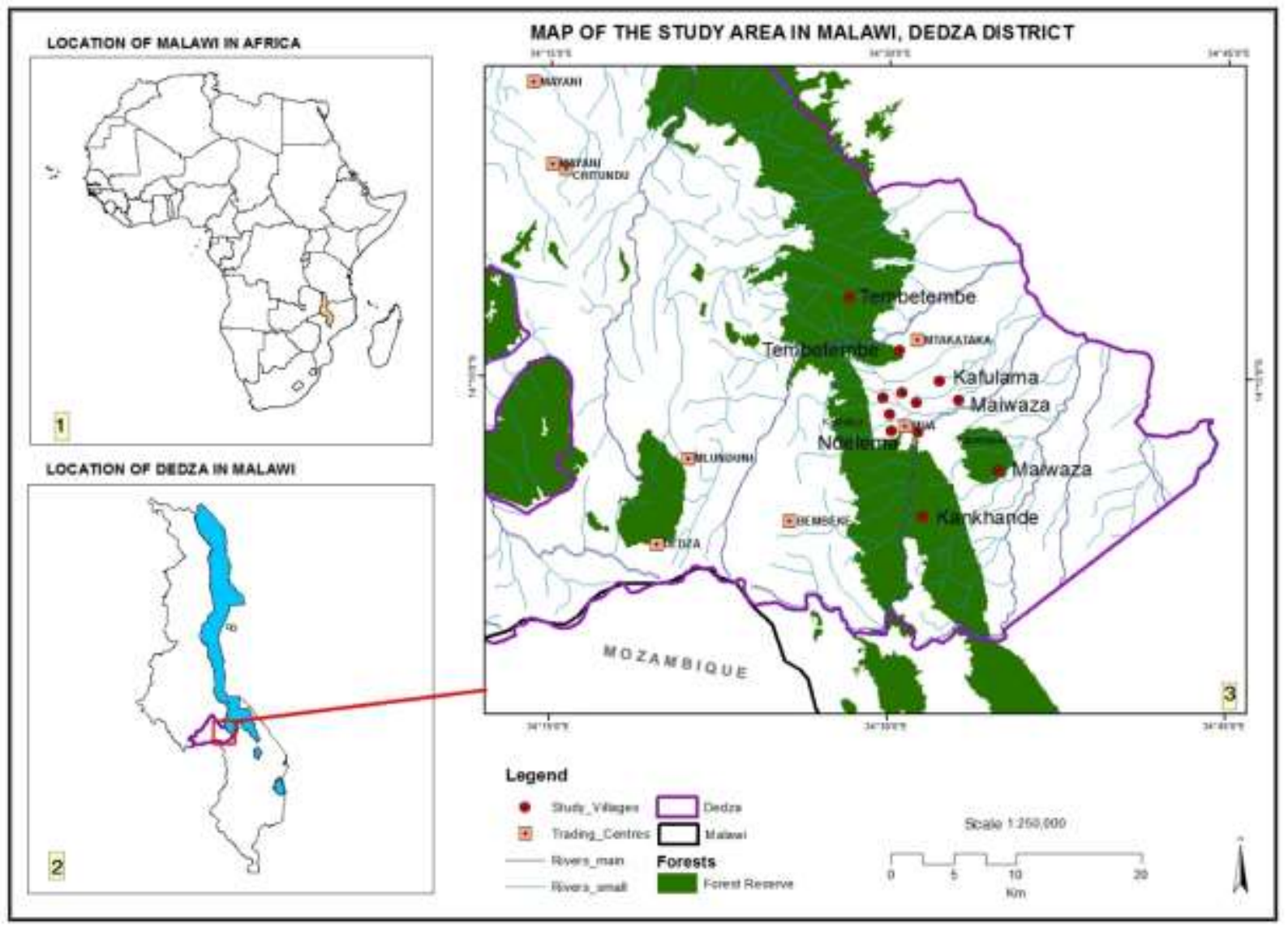

FIGURE 1 Map of study area (Source: GIS Unit, Forestry Department, Malawi)

The research targeted co-management sites and therefore Mua-Livulezi Forest Reserve, being one of the target forest areas for IFMSLP, and its adjacent communities were purposively selected to suit the focus and context of the study. Purposive sampling is a non-probability sampling technique in which decisions regarding selection of the sample are based on a variety of criteria to select a sample that provides appropriate data, both in terms of relevance and depth (Palinkas et al., 2013, Palys, 2008, Suri 2011, Tongco, 2007). Eleven villages out of thirty seven participating villages (about 30\%) were randomly selected. The villages are in the area of Group Village Headman (GVH) Kafulama in Traditional Authority Kachindamoto, in Mtakataka, Dedza (GoM, 2013). A list of households for each village was developed based on information from village registers provided by village headmen. Proportional random sampling was used to select households for interviews to allow for a representative sample from each village and reduce sampling error (Palinkas et al., 2013, Schaeffer et al. 2012). Each village was taken as a subpopulation and sample size in each village was allocated proportional to its population. Thereafter random sampling was applied to select the individual households for interviews.

Three data collection methods were used namely: focus group discussions, household and group interviews. Household interviews were conducted with the head of household or an adult person (in the absence of head of house) to represent the views of the selected household. A total 
of 300 household were interviewed using a structured questionnaire. In cases where the household could not be interviewed, the next randomly selected household on the sampling framework was selected. For the group interviews, the LFOs were also purposively selected to include only those that were developed using the guidelines in the PFM process. Group interviews were conducted with LFOs committee members using a structured questionnaire.

Focus group discussions were conducted with both members and non-members of the LFOs using a semi-structured questionnaire. The LFOs included block management committee (BMC), village natural resources management committee (VNRMCs), forest user groups and the chief's committee. The discussions were conducted to get an overall impression of the institutional arrangements for participatory forestry management in the area. A Likert scale was used to measure all the focus group discussion aspects related to performance of the LFOs.

Data obtained through the structured questionnaire were coded and processed using Statistical Package for Social scientists (SPSS ver22) to generate descriptive statistics. The descriptive statistics developed were for membership in forest groups, reasons for membership and non-membership in forest groups, knowledge of forest access procedures, and perception of changes in granting permission to access and harvest forest products. Data obtained through group interviews with local forest organizations and group discussions with committee and noncommittee members of LFOs were compared against what Agrawal (2001) recommended as critical enabling conditions (the resource system characteristics, group characteristics, institutional arrangements and the external environment) for sustainable management of commonly managed resources (Agrawal 2001, pg. 1659). These factors are the components parts of the Institutional Analysis and Development (IAD) framework developed by Ostrom (1999) (Agrawal, 2001).

\section{RESULTS AND DISCUSSION}

\section{The institutional Framework of Mua-Livulezi Forest Reserve, Dedza, Malawi}

This section reports on the institutional framework put in place for the implementation of comanagement of Mua-Livulezi forest reserve. It presents results on the process followed in instituting the different levels of local forest organizations (LFOs), and their roles and responsibilities as stipulated in the co-management agreement.

Institutional arrangements are defined in many different ways but are often referred to as the 'rules of the game' or 'how things are and should be done' (Regmi et al. 2008). They can be classified as formal (rules, laws, constitutions, organizational entities) and informal (norms of behaviour, conventions, and codes of conduct) practices that structure human interaction (Armitage et al. 2009). In this study, the institutions refer to the formal organizational structures, norms and rules.

The design of the co-management program in Malawi allows for the creation of multi-level Local Forest Organizations (LFOs, Fig 2). The process involved organization of the local communities in product specific Forest User Groups (FUGs), providing for a platform for forest users to actively participate in forest management. Members of the FUGs nominated representatives which were elected members of the Village Natural Resources Management Committee (VNRMC). 
LOCAL FOREST ORGANISATIONS (LFOS)

Local forest

Management Board

\section{DESCRIPTION AND FUNCTIONS/RESPONSIBILITIES}

- To provide the strategic context for planning and coordinating site level community comanagement agreements and benefit sharing from the forest reserve.

- To provide monitoring and supervisory function in the management of the reserve across blocks and reconciling multiple interests for integrated management

- To facilitate, co-ordinate, advise, monitor and provide a forum for conflict resolution in line with the Strategic Forest Reserve Area Plan

\section{Block Management Committee}

- Blok management committee is comprised of representatives from VNRMCs adjacent to the co-management block responsible for forest planning management and administration of the co- management agreement

\section{Village Natural Resources Committee}

-This committee comprises forest users who organize themselves to elect a committee whose role is to represent their interest and act as a liaison in dealing with forest extension workers and other government officials.

- The VNRMC is responsible for forest planning, management and administration and might also take on other roles in natural resource management.

\section{Forest User Groups}

- Groups of people residing closer to forest area entrusted to manage, conserve, develop and utilize forest products in Forest Management Units (FMUs) as per product.

- Actively involved in PFM processes including development of constitution, management plans for the forest area (block) and implementation of management strategies.

FIGURE 2 Local Forest Organizations for implementation of co-management. 
VNRMC members from different villages under one Group Village Headman (GVH) nominated and elected members of a Block Management Committee (BMC). At district level, a multi-stakeholder body, the Local Forest Management Board (LFMB) was developed comprising elected representatives drawn from local people, traditional authorities, government, local government (District Council), religious leaders, other non-government organizations, and the private sector. Figure 1 provides the linkages between the different LFOs. These LFOs receive legitimacy through the process of registration at District Forestry Office and the participatory development of the constitution and associated resource access, use and management rules at local level (Lockwood et al. 2010, Zulu 2013).

Several capacity building activities such as training in forestry policy, forestry management strategies, book keeping, leadership skills and field visits to other PFM sites, were organized to enable the LFOs assume their responsibilities. In addition, tool boxes containing license book, sales book, permit book, receipt book, cash book, inventory book, petty cash voucher, and an official stamp were provided to assist in record keeping. The responsibilities of the LFOs as stipulated in co-management agreement are indicated in Table 1.

TABLE 1 Local forest organisations responsibilities

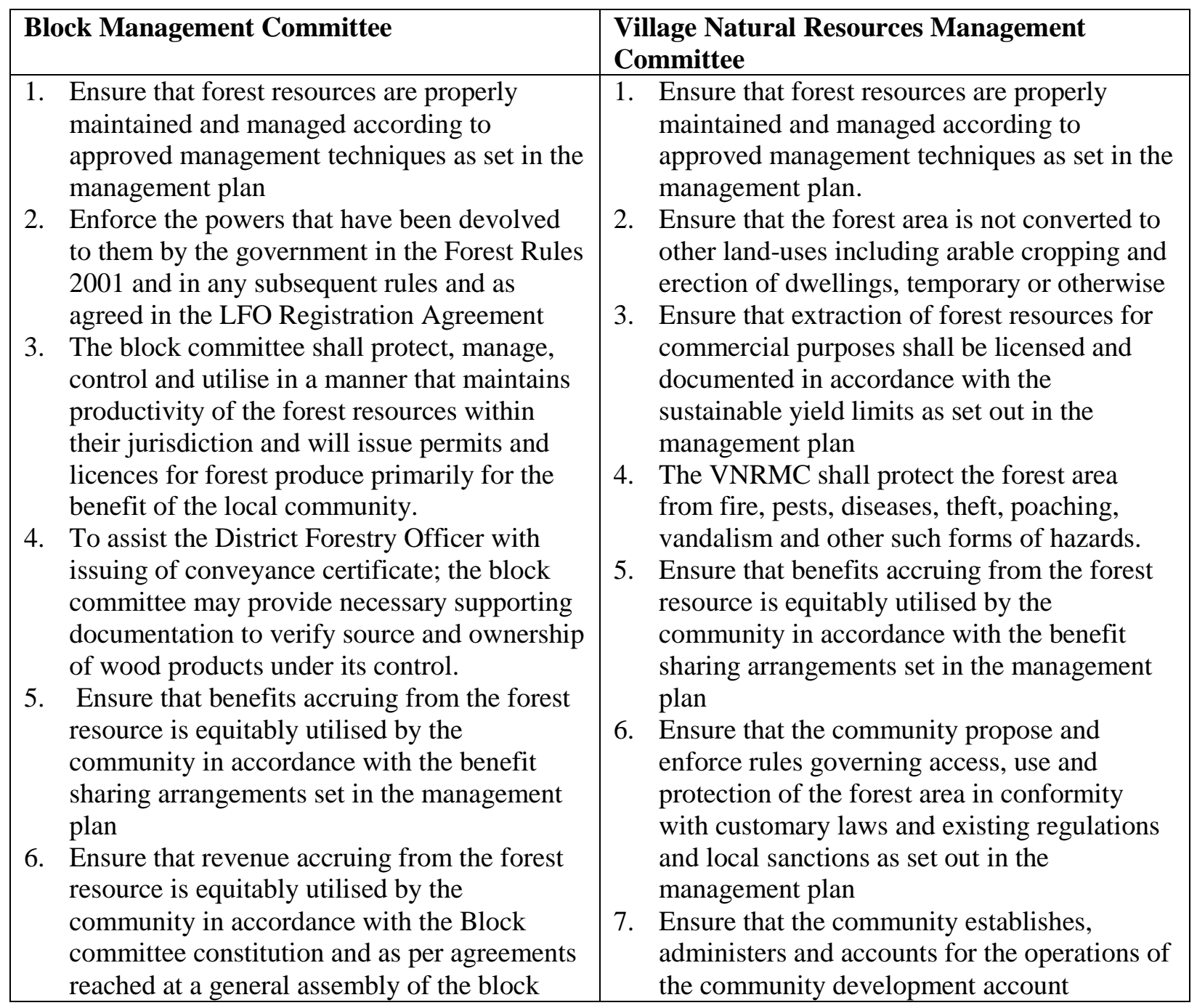


committee.

7. Ensure that $10 \%$ of the revenue accruing from the issue of commercial harvesting permits and licences is deposited in the account of the Local Forest Management Board on a quarterly basis.

8. Ensure that $30 \%$ of the revenue accruing from the issue of commercial harvesting permits and licences is deposited in the account of the District Forestry Officer for its transfer to the Forest Development Fund on a quarterly basis.

9. Ensure that a percentage of funds available to the block committee is utilised for the purposes of forest development and management.

10. The block committee will make accessible records of accounts and licences issued to the Director of Forestry or his/her representative, District Commissioner or his/her representative upon receiving notification .

11. The block committee shall represent and be accountable to the community and operate in accordance with the agreed constitution.
8. The VNRMC shall prepare financial reports to be presented at regular meetings to the community.

9. The VNRMC will make accessible records of accounts to the Director of Forestry or his/her representative, District Commissioner or his/her representative upon receiving notification

10. The VNRMCshall represent and be accountable to the community and operate in accordance with the agreed constitution.

11. The VNRMC shall delineate and maintain boundaries of the forest areas to be under the control of the local community in collaboration with local leaders.

Source: GoM, 2005

\section{Existence of and membership in local forestry organizations in the study area}

This section details the existing situation, at the time of study, of the existence of the different local forest organization (LFOs) and involvement of local people as LFO members.

The success of participatory forest management (PFM) relies on the collaboration of local people for long-term resource management using local groups as alternative to strict regulation and enclosure (Pretty, 2003). The co-management program facilitated formation and strengthening of new multi-level local forest organizations which included the block management committee (BMC), village natural resources management committees (VNRMC), and forest user groups (FUGs). This arrangement is consistent with the recommendation by Armitage et al. (2009), Lockwood et al. (2010) and Zulu (2012), which championed for multilevel institutional arrangements that bridge disparities at the different levels and allow management and social learning at multiple levels concurrently. The creation of these organizations represented a new social capital for the communities. It is argued that high levels of social capital increases collective action and conformity to rules required for long term sustainability (Gibson et al. 2005). At the time when this study was conducted, there was a BMC, six VNRMCs and two forest user groups which were developed through the PFM process. The BMC is known as Kafulama BMC; the VNRMCs are Kafulama, Kalindiza, Kanyera, Kamchamba, Alufeyo and Tembetembe associated with villages with the same names. The forest user groups were involved in bee keeping and curio making (wood carving). However, household interviews revealed that $74.30 \%$ of the respondents did not belong to any forestry 
related group despite co-management being implemented for close to 5 years in the area. The respondents mentioned several reasons for not belonging to an FUG. The representation in the different LFOs and reasons for non-membership of FUGs are presented in Table 2. Discussions with members of LFOs indicated that the FUGs ceased to exist soon after management plans for the block and village forest area were developed. This was attributed to failure to develop forest based enterprises further. Creation of formal user groups has been reported to be a key mechanism in enhancing participation of community members in forest management and therefore, generate more functional communities and PFM incentives (Adhikari et al. 2007, Agrawal and Gupta 2005, Kabubo-Mariara, 2008, 2009, Zulu, 2012). However, in our study, the committees were the actual implementers (calling themselves volunteers) rather than community representatives and coordinators in the implementation of forest management activities.

TABLE 2 Representation in LFOs and reasons for non-membership of forest user groups in Mtakataka $(n=288)$

\begin{tabular}{lll}
\hline Aspect & Frequency & Percentage \\
\hline Representation in LFOs & & \\
No membership & 216 & 74.3 \\
Block committee & 10 & 3.5 \\
VNRMC & 57 & 19.8 \\
FUG & 7 & 2.4 \\
\hline Reason & & \\
No FUG exist in the village & 118 & 41.0 \\
Does not have time for forestry activities & 65 & 22.5 \\
Interested to join but need more information & 34 & 11.8 \\
FUG members belong to a specific group & 26 & 9.1 \\
I cannot afford the membership fee & 17 & 5.9 \\
No interest in FUG activities & 9 & 3.1 \\
FUG membership would restrict my forest use & 7 & 2.4 \\
FUG not effective in managing the forest area & 6 & 2.1 \\
Wary of forestry authorities & 6 & 2.1 \\
\hline
\end{tabular}

The role of traditional leaders should not be underestimated when it comes to management of forest resources. The traditional leaders play a crucial role at all levels: village headman, group village headman, sub-traditional authority [STA] and traditional authority [TA]). They are the custodians of customary lands and local knowledge and customs, resolve conflicts and mobilize the wider community for participation in the implementation of PFM activities (Campbell and Shackleton 2001, Zulu 2012). The co-management process provides for traditional authorities as members of the local forest management board (GoM, 2010). However, village headmen have no direct role in forest management (GoM 2003). Therefore, more recently (2013), a Chief's Committee was constituted comprising village headmen from villages participating in co-management to work hand in hand with the block committee. This was felt would increase their participation in forest activities and enable them provide necessary support for implementation of planned forest activities. In addition, this would strengthen the connection of VNRMCs to the district decentralization set up, since VNRMCs report to village headmen through the village development committee (Figure 3). However, this committee was still in its 
infancy stage at the time of data collection for this research; hence the roles and responsibility of the committee in co-management were not further investigated.

However, there is need to be cautious over involvement of traditional leaders in natural resources management, as there are examples from Malawi, of both successful Community Based Natural Resources Management (CBNRM) (Mauambeta et al. 2007, Mumba 2003, Russell et al. 2008, Zulu 2008) and failure and conflicts in CBNRM (Chinsinga 2005, Shackleton et al. 2002, Zulu 2008), attributed to traditional leadership. In this regard, development of village heads' capacity through training could assist to further improve their leadership skills as they relate to forest management. They could assist in balancing power between the committee and the wider community which is pertinent to mediating any disputes and conflicts related to forest access and forest management in general (Zulu, 2008).

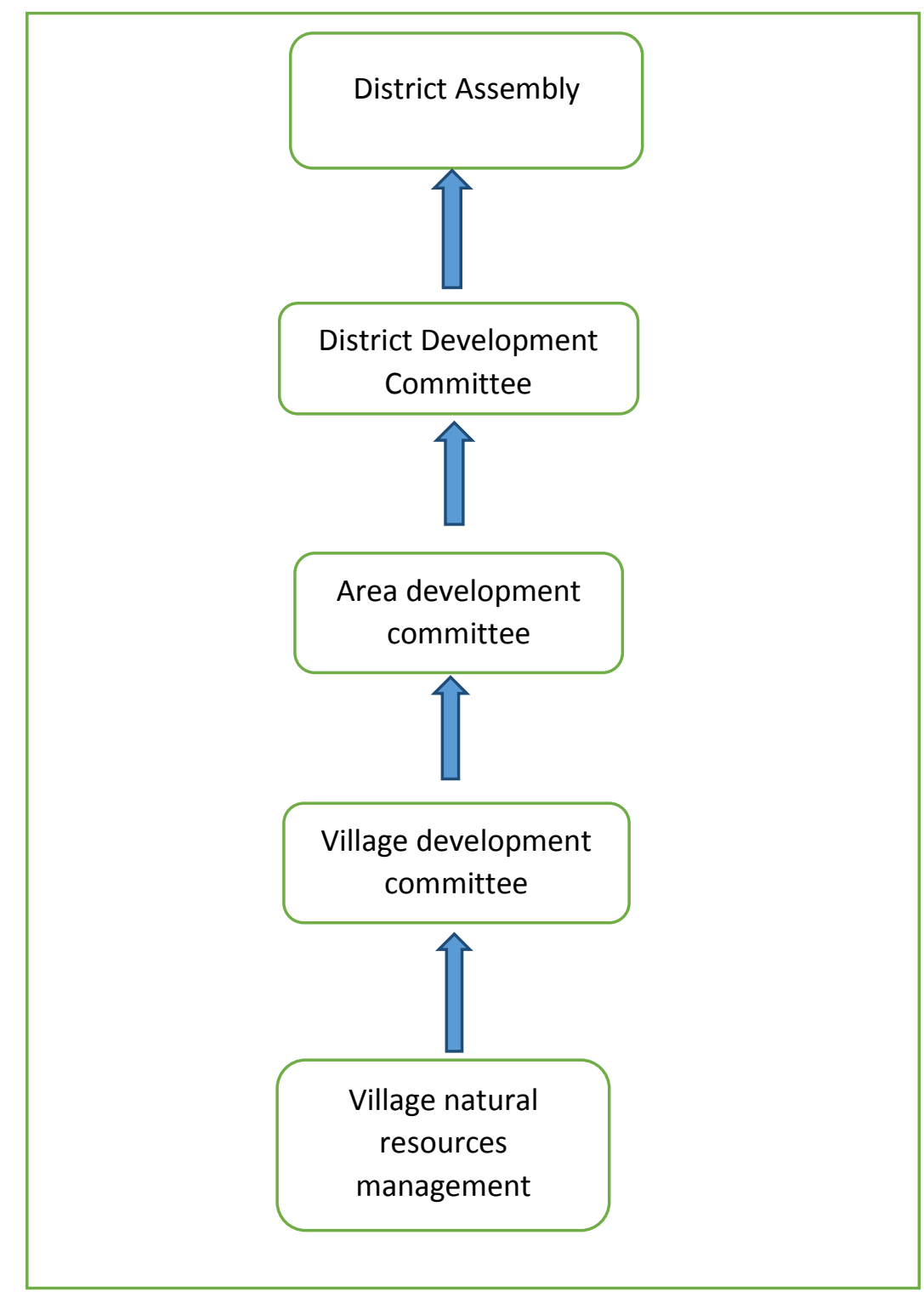

FIGURE 3 Linking the VNRMC to the decentralisation set up at district level 
The afore-mentioned local forest organizations were formed starting in 2006 and were still in existence at the time of data collection. Most of these organizations were formed through government initiatives and members were elected through democratic process involving the wider community. All the identified organizations had a constitution and their activities were guided by the content of the constitution. In addition, the constitution detailed the composition and the roles and responsibilities of executive members of the LFOs.

\section{Effectiveness of Local Forest Organization}

Effectiveness of local forest organisations was assessed in two ways. First the LFO members were asked to indicate their perception of various aspects related to the performance of the LFOs. The aspects included participation of members within the LFO, functioning of the LFO, participation of non-committee members in LFO activities, adherence to rules, support from traditional leaders, and relation and trust of LFO members to Department of forestry (FD) personnel.

Table 3 presents the results of the perception of the LFOs members related to performance of LFOs. Participation of committee members within the LFO was above average $(>3)$ for most of the LFOs. Participation of non-committee members in LFO activities, such as meetings and forest operations, was below average (mean $=2.6$ ) across all LFOs. This was attributed to incomplete community mobilisation which resulted in weak linkages between committee and non-committee members.

The PFM standards and guidelines define a LFO (VNRMC) as having three levels: a management committee ( $\geq 10$ members), a general body (all interested and active members) and the wider community (GoM 2005). However, only the management committees were active. Such scenario has potential to lead into creation of village elites and therefore alienation of the wider community as decision making is controlled by few individuals (Kellert et al. 2000, Zulu 2008). This also affected information exchange and knowledge transfer between the committees and the wider community as evidenced by non-attendance of meetings. However, the most important and positive aspect of the co-management process is that the committees were formed following a participatory process.

Adherence to rules was average (mean $=3$ ) indicating a worrisome trend. Rules lose their power if they can be easily broken (Horning 2005), resulting in degradation of the resource. Collective outcomes can be achieved when individuals act in common interest (Shrestha and McManus 2006) in ensuring that forest management strategies can successfully contribute to livelihood and conservation outcomes.

Most of the LFOs were functional, with an average score of 3.3. They also indicated that they received support from traditional leaders especially with mobilisation of non-committee community members to participate, and enforcement of rules and sanctions (mean score=3.4). There was also above average level of trust and relationship between the LFOs and department of forestry personnel. Greater access to government officials increases level of participation of members of local groups and therefore performance of the groups (Agrawal and Gupta 2005). Lockwood et al. (2009) also reported that community collaboration is dependent on trust and confidence the community has in service providers. The Forestry Department, therefore, needs to provide continued support in areas such as organizational and financial management, law enforcement, and development of forest based enterprises, including identification of markets. This would facilitate a process that is institutionally sustainable and 
spatially replicable (Ribot 2003), resulting in a strong local organizational capacity and political capital that is necessary to reap benefits from forest management (Ribot 2003, Shackleton et al. 2002).

On interaction with other actors in forest management, the LFOs indicated that they interacted with non-governmental organizations such as: Climate Adaptation for Rural Livelihoods and Agriculture (CARLA), Total Land Care and the World Agroforestry Centre. These organizations were involved in the provision of inputs and technical support for tree planting, land conservation and agroforestry. 
TABLE 3 Performance of LFOs

\begin{tabular}{|c|c|c|c|c|c|c|c|c|}
\hline \multirow{2}{*}{ Aspect } & \multicolumn{8}{|c|}{ Village Natural Resources Committees } \\
\hline & $\begin{array}{l}\text { Block } \\
\text { Management } \\
\text { Committee }\end{array}$ & Kafulama & Kalindiza & Kanyera & Kamchamba & Alufeyo & Tembetembe & Mean Scores \\
\hline $\begin{array}{l}\text { Participation of committee } \\
\text { members in } \mathrm{LFO}^{1}\end{array}$ & 5 & 5 & 3 & 4 & 3 & 4 & 3 & 3.9 \\
\hline Functioning of the $\mathrm{LFO}^{2}$ & 4 & 4 & 3 & 3 & 3 & 3 & 3 & 3.3 \\
\hline $\begin{array}{l}\text { Participation of non- } \\
\text { committee members in LFO } \\
\text { activities } 1\end{array}$ & 3 & 3 & 2 & 2 & 3 & 3 & 2 & 2.6 \\
\hline Adherence to rules ${ }^{1}$ & 4 & 3 & 2 & 4 & 3 & 3 & 2 & 3 \\
\hline $\begin{array}{l}\text { Support from Traditional } \\
\text { leaders }\end{array}$ & 4 & 4 & 3 & 4 & 3 & 3 & 3 & 3.4 \\
\hline $\begin{array}{l}\text { Relationship with FD } \\
\text { personnel }^{1}\end{array}$ & 5 & 5 & 4 & 3 & 4 & 3 & 3 & 3.9 \\
\hline $\begin{array}{l}\text { Trust of LFO members to } \\
\text { FD personnel }\end{array}$ & 5 & 5 & 4 & 4 & 4 & 3 & 3 & 4 \\
\hline
\end{tabular}

Rating: ${ }^{\prime} 1$ = very low, $2=$ low, $3=$ average, $4=$ high, and $5=$ very high;

$:{ }^{2} 0=$ dormant, $1=$ very inactive, $2=$ inactive, $3=$ active, and $4=$ very active 
Secondly, the effectiveness of the LFO to achieve sustainable forest management was measured by asking the LFO members to indicate the ease with which they were able to fulfil their responsibilities as stipulated in the co-management agreement. The responsibilities were summarised as contribution towards sustainable forest management (SFM) (Table 4) as indicated by Yami et al. (2009). They were also asked to indicate the conditions that were either enhancing and/or hindering achievement of the expected outcomes. Table 4 presents the results of the discussion with the LFOs. The discussions revealed more hindering conditions than enabling conditions. The LFOs were not fully empowered such that they often relied on traditional leaders to call for meetings whenever they needed input from villagers on issues related to forest management. Participation of villagers was also dependent on how they perceived benefits for their participation. While other programs such as Climate Adaptation for Rural Livelihoods and Agriculture (CARLA) provided goats to people for participating in their activities, the IFMSLP program did not. As such, people preferred to participate where they could get immediate benefits. This therefore denied the program of the necessary social capital to achieve collective action. Collective action in forestry has been recognized as vital for effective management of forests (Ostrom, 1990, Shrestha and MacKanus, 2006), since collaboration can foster shared ownership and responsibility which could lead to sustainable management of the forests (Byran, 2004). This is based on the assumption that involvement of local communities could improve forest condition and utilization. Furthermore, Gibson et al. (2005) and Ostrom (1990) suggested that high levels of social capital and collective action arrangements could sustain regular monitoring of rule enforcement needed for long-term sustainability.

Although the LFO conducted regular forest patrols, they rarely apprehended offenders. When they did and the offenders were taken to court, the penalties meted out were so minimal to act as a deterrent to the offender. This development combined with inadequate human capacity versus the size of the forest area, to monitor use and sanction rules, had negatively affected the functioning of the LFOs to manage the forests in a sustainable manner. Illegal harvesting of timber and bamboo, and opening up of large areas for farming and settlement were increasing resulting in degradation of the forest. This finding is supported by Girma (2005), Kigenyi (undated) and Owubah et al. (2001), who indicated that lack of capacity to control illegal activities, inadequate human capacity and inadequate supervision lead to decline in forest condition.

Effective performance of local institutions is often hindered by high transaction costs and poor funding (Zulu, 2012). The benefit sharing mechanisms provided for in the co-management program had provided the LFOs with funding to meet some of their costs. The revenue generated from fees and permits for forest products is shared between government and the community as follows: 60\% BMC (community); 30\% FD (government) and 10\% LFMB), as per co-management agreement (GoM, 2010). The cashbook managed by the BMC showed that since signing the co-management agreement the BMC had collected MK203, 727.00 (USD 468.57). Out of this MK73, 400 (USD 168.82) had been remitted to the forestry department and LFMB combined, while MK44, 327.00 (USD 101.95) was used to support the BMC activities especially forest patrols. The BMC had a balance of MK86, 000.00 (USD197.80). This source of funds provides an opportunity for the activities of the LFMB and BMC to be supported. As indicated by Andersen et al. (2007), these resources could enable the LFOs to meet the transaction costs required for cross-level coordination of forest management activities and re-invest in forest management and other community development activities as determined by the communities. 
TABLE 4 Conditions influencing effectiveness of LFOs

\begin{tabular}{|c|c|c|}
\hline Contribution towards SFM & Enhancing conditions & Hindering conditions \\
\hline $\begin{array}{l}\text { Creating space for forest users to } \\
\text { participate in decision making } \\
\text { processes }\end{array}$ & $\begin{array}{l}\text { Common platform for different } \\
\text { sector-committees to discuss } \\
\text { issues at village level }\end{array}$ & $\begin{array}{l}\text { - No authority - over reliance on } \\
\text { traditional leaders (VNRMC) } \\
\text { - Misconception of benefits }\end{array}$ \\
\hline $\begin{array}{l}\text { Enforcement of rules with } \\
\text { mutual agreement of users }\end{array}$ & $\begin{array}{l}\text { Availability of forests outside } \\
\text { forest reserve }\end{array}$ & $\begin{array}{l}\text { - Lack of legitimacy with } \\
\text { outsiders } \\
\text { - Lack of empowerment }\end{array}$ \\
\hline $\begin{array}{l}\text { Imposing locally agreed } \\
\text { sanctions }\end{array}$ & $\begin{array}{l}\text { Mutual understanding among } \\
\text { users }\end{array}$ & $\begin{array}{l}\text { Violators are rarely } \\
\text { apprehended }\end{array}$ \\
\hline $\begin{array}{l}\text { Regulating use of forest } \\
\text { resources }\end{array}$ & $\begin{array}{l}\text { High awareness among users of } \\
\text { the licensing system }\end{array}$ & $\begin{array}{l}\text { - Inadequate human capacity to } \\
\text { monitor use } \\
\text { - Individual needs superseding } \\
\text { communal needs }\end{array}$ \\
\hline $\begin{array}{l}\text { Equitable sharing of benefits } \\
\text { among users }\end{array}$ & & $\begin{array}{l}\text { - Benefits not clearly defined - } \\
\text { benefits equated to money } \\
\text { only } \\
\text { - Low levels of revenue } \\
\text { generated } \\
\end{array}$ \\
\hline $\begin{array}{l}\text { Application of local knowledge } \\
\text { to manage forest resources }\end{array}$ & $\begin{array}{l}\text { Active participation of traditional } \\
\text { leaders }\end{array}$ & $\begin{array}{l}\text { No platform for sharing } \\
\text { communities' own knowledge }\end{array}$ \\
\hline $\begin{array}{l}\text { Encouraging forest users to } \\
\text { manage forest resources }\end{array}$ & $\begin{array}{l}\text { High level of awareness among } \\
\text { users of the benefits from } \\
\text { forests and trees. }\end{array}$ & $\begin{array}{l}\text { - Need for immediate benefits. } \\
\text { - Less interaction between } \\
\text { committee and non- } \\
\text { committee members to } \\
\text { reinforce users to future } \\
\text { benefits. }\end{array}$ \\
\hline $\begin{array}{l}\text { Managing the forest area } \\
\text { according to plan (prevention } \\
\text { of forest degradation }\end{array}$ & $\begin{array}{l}\text { Regular monitoring and } \\
\text { sanctioning of rules }\end{array}$ & $\begin{array}{l}\text { - Inadequate human and } \\
\text { financial capacity } \\
\text { - Conflicts on forest use with } \\
\text { neighbouring blocks (changing } \\
\text { land use from forest to } \\
\text { farming) } \\
\text { - Low penalties handed down to } \\
\text { offenders by the courts (low } \\
\text { court fines) }\end{array}$ \\
\hline $\begin{array}{l}\text { Meeting economic needs of } \\
\text { forest users }\end{array}$ & $\begin{array}{l}\text { Issuance of licences for } \\
\text { commercial forest use }\end{array}$ & $\begin{array}{l}\text { - Non-existence of forest based } \\
\text { enterprises (forest reserve) } \\
\text { - Non-existence of mechanisms } \\
\text { to allow commercial forest } \\
\text { use (village forest areas) }\end{array}$ \\
\hline
\end{tabular}




\section{Forest access and access rules}

This section presents results on access to forest areas, the process followed to gain access and the rules governing access to forest areas.

\section{Access to forest area}

Table 5 indicates that the households had access to three communally 'owned' forest areas. However, the two forest areas linked to the co-management agreement were: a block in MuaLivulezi forest reserve and Kafulama village forest area. The boundaries of these forest areas were well-defined following historical (or natural) boundaries of the group village headman $(\mathrm{GVH})$. The users were also defined following similar criteria. The majority of the respondents $(86.2 \%)$ were within a distance of $\leq 5 \mathrm{~km}$ to the nearest forest area. The success of collective management of natural resources is more probable when boundaries are defined, users stationary (not nomadic), and benefits are predicted (Agrawal 2001). The flow of benefits was determined through participatory resource assessment which resulted in demarcation of the block into forest management units according to the key product in that particular area and determination of the annual allowable cut. This result mirrors that of Degefa (2010), Gibson et al. (2005) and Kellert et al. (2000), who indicated that defining boundaries of both the resource and users, reduced uncertainty on who will benefit and bear the cost of management, as well as ensure sustainable utilization of the resources.

TABLE 5Aspects of forest access

\begin{tabular}{lll}
\hline Aspect of forest access & Frequency & Percentage \\
\hline Forest area & 155 & \\
Forest reserve & 36 & 12.7 \\
Village forest area & 33 & 11.0 \\
Group/communal forest & 68 & 22.7 \\
Individual/private forest & 3 & 1.0 \\
Buying & 5 & 1.7 \\
Other people's forests & & \\
Distance to nearest forest area & 257 & 86.2 \\
0-5km & 33 & 11.1 \\
6-10km & 8 & 2.7 \\
11-15km & 174 & \\
Permission to enter forest area & 59.0 \\
Required & 22 & 33.6 \\
Not required & & \\
Do not enter forest & 193 & 65.4 \\
\hline Permission to harvest forest products & 64 & 21.7 \\
Required & 38 & 12.9 \\
Not required & & \\
Do not harvest & & \\
& 121 & 58.7 \\
\hline Permit granting authority for all forest products & & \\
Department of forestry &
\end{tabular}




\begin{tabular}{lll}
\hline VNRMC & 47 & 22.8 \\
Village Head & 24 & 11.7 \\
Owner of forest & 8 & 3.9 \\
FUG chairperson & 6 & 2.9 \\
\hline Permit fee & 169 & 58.4 \\
Yes & 79 & 28.1 \\
No & 38 & 13.5 \\
$\quad$ Do not harvest forest products & & \\
$\quad$ & & \\
Change in granting permission & 114 & 42.1 \\
$\quad$ Over last five years & 86 & 31.7 \\
$\quad$ No & 71 & 26.2 \\
$\quad$ Do not know & 109 & 41.3 \\
$\quad$ Yes & 80 & 30.3 \\
$\quad$ In future & 75 & 28.4 \\
$\quad$ Do not know & \\
$\quad$ Yes & 65 & 29.5 \\
$\quad$ No & 60 & 27.3 \\
$\quad$ Reasons for response & 26 & 11.8 \\
$-\quad$ Unaware of the process and past trends & 10.9 \\
$-\quad$ To protect and sustain forest resources & 10.5 \\
$-\quad$ Have not changed for a long time & 24 & \\
$-\quad$ Change in operating environment & 23 & \\
$-\quad$ Change in governance of forest resources & & \\
$\quad \quad$ &
\end{tabular}

For the process of issuing permits for forest use, $42.1 \%$ of the respondents indicated that the process of issuing permits for forest use had not changed over the last five years. A further $31.7 \%$, did not know whether the process had changed or not. This result indicated that, despite the co-management agreement, authority to license forest use had not been completely handed over to, and institutionalised within the community organizations. Introduction of comanagement, however, resulted in regulated access to products and services. This change resulted in both positive and negative effects on people: some walked long distances to get forest products; some reduced reliance on forest products; and others turned to alternatives to forest products, while for others the opposite was true. Similar outcomes were reported by Kajembe and Kessy (2000) in Tanzania where participatory forestry management was adopted for management of Urumwa forest reserve. The other change that occurred at the onset of comanagement, was the requirement to pay fees prior to harvesting forest products for sale. This institutional arrangement had increased income sources for the community but Vyamana et al. (1996) indicated that such change could become a disadvantage to the very poor and poor households who could not afford to pay the user fees to harvest forest products for sale. Looking to the future, there was no statistically significant difference between those that thought the process of permission would change $(30.3 \%)$ and those that thought that it would remain the same $(28.4 \%)$. 


\section{Forest Access rules}

Rules define what is 'required, prohibited, or permitted' and is central to the functioning of the institutions governing commonly managed natural resources (Agarwal 2009, Horning 2005). Table 6 indicates that the households interviewed showed a high level of awareness, but low levels of compliance and enforcement of both customary and government rules that regulate access into the forest reserve. However, only a few offenders were penalised.

TABLE 6 Perception of forest access rules

\begin{tabular}{|c|c|c|c|}
\hline Type of rules & Aspect of access rules & Frequency & Percentage \\
\hline \multirow[t]{13}{*}{ Customary } & Existence & & \\
\hline & Yes & 257 & 87.7 \\
\hline & No & 36 & 12.3 \\
\hline & Respect & & \\
\hline & Yes & 225 & 81.5 \\
\hline & No & 51 & 18.5 \\
\hline & Enforcement & & \\
\hline & Yes & 240 & 87.9 \\
\hline & No & 33 & 12.1 \\
\hline & Violation & & \\
\hline & No & 209 & 73.3 \\
\hline & Yes & 69 & 24.2 \\
\hline & I would rather not say & 7 & 2.5 \\
\hline \multirow[t]{16}{*}{ Government } & Existence & & \\
\hline & Yes & 252 & 85.1 \\
\hline & Do not know & 29 & 9.8 \\
\hline & No & 15 & 5.1 \\
\hline & Respect & & \\
\hline & Yes & 206 & 73.3 \\
\hline & No & 47 & 16.7 \\
\hline & Do not know & 28 & 10.0 \\
\hline & Enforcement & & \\
\hline & Yes & 235 & 84.5 \\
\hline & Do not know & 29 & 10.4 \\
\hline & Not & 14 & 5.0 \\
\hline & Violation & & \\
\hline & No & 208 & 70.7 \\
\hline & Yes & 75 & 25.5 \\
\hline & I would rather not say & 11 & 3.7 \\
\hline \multirow[t]{3}{*}{ Both } & Penalties & & \\
\hline & No & 267 & 89.0 \\
\hline & Yes & 33 & 11.0 \\
\hline
\end{tabular}


The success of managing collective resources is dependent on the ability of users to collectively devise rules for access and protection of the resources (Marothia, 2003, Stern et al., 2002). The management plans for the forest reserve indicated two set of rules: general resource rules and product use rules (Department of Forestry, 2007a, b). The general resource rules applied to all products in general and were related to what activities and products were allowed or not, and procedure to follow to access/harvest forest products (permit). The rules also spelt out the penalties imposed when one contravenes them. An example of a general rule was 'cutting of live trees is prohibited without a permit', whose penalty was MK2, 000.00 (USD4.60). Product use rules indicated what was allowed and not allowed for particular forest products to be harvested from the forest area, as well as permit fees for the specific product and its derived products, if any. An example of a product rule was 'harvesting of timber, poles, firewood (for sale) shall be in demarcated coupes only'. The permit fees for timber, firewood and poles were MK3,000.00 (USD6.90) per tree, MK500 (USD1.15) per cubic metre and MK50 (USD0.12) each, respectively. The important role of product use rules is stressed by Agrawal and Yadama, (1997) who indicated that product use rules assist in mediating pressures exerted on the forest resources by markets and population demands. This role was recognised against the background of good roads connecting the villages within study site to major towns and illegal harvesters that took advantage of this opportunity and got away due to inadequate enforcement of the rules. Rules therefore, need to be enforced if they are to influence behaviour and cooperation among community members, but this requires that there be "intolerant enforcers" (Horning 2005, Kameda et al. (2003) in Gibson et al. 2005). The LFOs were able to enforce rules within their area of jurisdiction. However, they were unable to exercise their authority on outsiders who encroached in the reserve establishing farmlands and homesteads. The change in land use brought negative consequences such that three irrigation canals dried up. Therefore, we echo the recommendation of Chakraborty (2001) that a strong system of authority combined with external support in rule enforcement could help to stabilize functioning of the LFOs. It is hoped that this would increase their ability to monitor and sanction forest use. Effective monitoring and sanctioning of forest use increases the probability of achieving institutional sustainability (Agarwal 2009, Kellert et al. 2000) and a long-term condition of a better managed forests (Gibson et al. 2005, Horning 2005).

\section{CONCLUSION}

This study examined the potential of local institutions in implementing co-management of MuaLivulezi Forest Reserve in Mtakataka EPA in Dedza District of Malawi. Co-management created new democratic local forest organizations BMC and VNRMC, which represented a new social capital for the community. However, the non-existence of FUGs created a gap to achieve popular participation of the non-committee community members in co-management activities. This implied that the LFOs could not effectively influence collective action required for improvements in both socio-economic and biophysical factors in the local context. This could be reversed if a 'broad based community empowerment' approach was adopted through rejuvenation of FUGs which, in turn, would enable community members to participate and demand accountability from their LFOs. It is recommended that forestry extension workers on the ground should be provided with the necessary technical support to facilitate such a process. 
This would ensure that co-management is indeed a community forest program and not committee forest program as is the case at present.

Co-management has created the potential for the LFOs to achieve sustainable management of forest resources. However, challenges still exist. The potential of the LFOs to contribute towards sustainable forestry management had been negatively affected by a number of factors including lack of empowerment and legitimacy, inadequate human and financial capacity, and conflicts on forest use. There is need to enhance the effectiveness of the LFOs by improving the conditions that are hindering their contributions to sustainable forest management. In this regard, the Department of Forestry and other service providers need to provide continued support in areas such as organizational and financial management, law enforcement, and development of forest based enterprises, including identification of markets.

Overall, co-management has initiated a process of fulfilling the different aspects of the enabling conditions under which local organizations can successfully manage their common resources under these conditions. The forest area and the community involved have clear boundaries as agreed and documented in the management plans for the forest areas. Two set of rules were collectively devised, however, enforcement is lacking. The LFOs therefore, should be adequately supported to effectively enforce rules and counter any conflicts that might arise in the process. In addition, the LFOs should be encouraged to follow what was jointly agreed upon and documented in the management plans. The management plans should also be regularly evaluated and effectively monitored for sustainable management and use of the forest products. This could therefore, enhance collective action through use of local knowledge and strategies to achieve livelihood and forest outcomes.

\section{ACKNOWLEDGEMENTS}

Acknowledgment to the University of Pretoria for provision of the Postgraduate bursary to the first author which enabled her to undertake this study. Field work for this research was supported by World Wide Fund for Nature through the Russell E. Train Education for Nature (EFN) Program. Thanks to the local forestry organizations (LFOs) and community members sampled in Mua and Mtakataka for their contribution to this study. Appreciation also goes to the Diploma class at Malawi College of Forestry and Wildlife (DCT23) and to the District Forestry staff at Dedza Boma and Mtakataka EPA for all the support during data collection.

\section{REFERENCES}

ADHIKARI, B., WILLAMS, F. and LOVETT, J. C. 2007. Local benefits from community forests in the middle hills of Nepal. Forest Policyand Economics 9: 464-478.

AGRAWAL, A. 2001. Common property institutions and sustainable governance of resources. World Development 29 (10): 1649-1672.

AGRAWAL, B.2009. Rulemaking in community forestry institutions: The difference women make. Analysis. Ecological Economics 68: 2296-2308.

AGRAWAL, A. and YADAMA, G.N. 1997. How do local institutions mediate market and population pressures on resources? Forests Panchayats in Kumaon, India. Development and Change 28: 435-465. 
AGRAWAL, A. and GUPTA, K. 2005 Decentralization and Participation: The Governance of Common Pool Resources in Nepal's Terai. World Development 33 (7):1101-1114.

ANDERSEN, K.F., GONDWE, E. and MUMBA, R.2007. Getting the institutional setup right A lessons learnt study from the BHA Lake Chirwa Project. In: NIELSEN, E. AND

RASMUSSEN, P. (ed.)Community based wildlife management in Malawi. Proceedings of a national conference, Capital Hotel, Lilongwe, 6-7 November. CURE/ WESM/DHA, 55-63.

ANDERSSON, K. 2006. Understanding decentralized forest governance: an application of the institutional analysis and development framework. Sustainability: Science, Practice and Policy 2(1): 25-35.

ARMITAGE, D.R., PLUMMER, R., BERKES, F., ARTHUR, R.I., CHARLES, A.T., DAVIDSON-HUNT, I.J., DIDUCK, A.P., DOUBLEDAY, N.C., JOHNSON, D.S., MARSCHKE, M., MCCONNEY, P., PINKERTON, E.W. and WOLLENBERG, E.K. 2009. Adaptive co-management for Social-Ecological Complexity. Frontiers in Ecology and the Environment 2: 95-102.

BALLABH, V., BALOONI, K. and DAVE, S. 2002. Why local resources management institutions decline: A comparative analysis of van (forest) panchayats and forest protection committees in India. World Development 12: 2153-2167.

BRYAN, T.A. 2004. Tragedy averted: The promise of collaboration. Society and Natural Resources 17: 881 - 896.

CAMPBELL, B.M. and SHACKLETON, S.2001.The organizational structures for communitybased natural resources management in southern Africa. African Studies Quarterly 5 (3).

CAMPBELL, B.M., SHACKLETON, S. and WOLLENBERG, E. 2003. Overview: Institutional arrangements for managing miombo. In:KOWERO G., CAMPBELL B.M. AND SUMAILA U.R. (ed.)Policies and Governance Structures in Woodlands of Southern Africa. Centre for International Forestry Research, Indonesia. 438pp.

CAMPBELL, B., MANDONDO, A., NEMARUNDWE, N., SITHOLE, B., DE JONG, W., LUCKERT, M. and MATOSE F. 2001. Challenges to proponents of common property resource systems: Despairing voices from the social forests of Zimbabwe. World Development 29(4): 589-600. Available at: http://linkinghub.elsevier.com/retrieve/pii/S0305750X00001145.

CHAKRABORTY, R.N. 2001. Stability and outcomes of common property institutions in forestry: evidence from the Terai region of Nepal. Ecological Economics 36: 341-53.

CHINSINGA, B. 2005. The interface between tradition and modernity: The struggle for political space at the local level in Malawi. Civilizations 54 (1/2): 255-274.

CLEMENT, F.2009. Analysing decentralized natural resource governance: proposition for a "politicized" institutional analysis and development framework. Policy Sciences 43 (2): 129156.

DEGEFA, M.Y. 2010. How informal institutions strengthen sustainable managementof common pool resources in Tigray, Ethiopia? Unpublished PhD thesis. University of Natural Resources andApplied Life Sciences, Vienna. Centre for Development Research

DEPARTMENT OF FORESTRY. 2007a.Mua-Livulezi Strategic Forest Area Plan. Dedza, Malawi

DEPARTMENT OF FORESTRY. 2007b. Management Plan for Kafulama Forest Block, GVH Kafulama, TA Kachindamoto, Dedza, Malawi

DEPARTMENT OF FORESTRY. 2007c. Management Plan for Kafulama VFA. Dedza, Malawi 
GERMAN, L.A. and KEELER, A. 2010. "Hybrid institutions": applications of common property theory beyond discrete property regimes. International Journal of the Commons 4: 571-596

GIBSON, C.C., WILLIAMS, J.T. and OSTROM, E., 2005. Local enforcement and better forests. World Development 33 (2): 273-284.

GOM. 2003. Community based forest management in Malawi: supplement to the national forest policy. Department of Forestry, Lilongwe, Malawi.

GOM. 2005. Standards and Guidelines for Participatory Forestry in Malawi. Department of Forestry, Lilongwe, Malawi.

GOM. 2010. Putting PFM into practice.A field and lessons manual for participatory forest management in Malawi. Department of Forestry, Lilongwe, Malawi.

GOM. 2013. Dedza district socio-economic profile 2013 - 2018.

IFMSLP. 2011. Final Evaluation of Improved Forest Management for Sustainable Livelihoods Programme, Malawi. European Union/Transtech Project Management.

HORNING, N.R. 2005. The cost of ignoring rules: forest conservation and rural livelihoods outcomes in Madagascar. Forests, Trees and Livelihoods 15: 149-166.

KABUBO-MARIARA, J. 2008. Forest dependence and household welfare: Empirical evidence from Kenya. CEEPA Discussion Paper No. 41. University of Pretoria, South Africa.

KABUBO-MARIARA, J. 2009. Making the link between forests and poverty reduction: a resource evaluation Study from Kenya/ 'Forest dependence and household welfare: empirical evidence from Kenya'. A summary of CEEPA Discussion Paper No. 41.

KAJEMBE, G.C. AND KESSY, J.F. 2000. Joint forest management in Urumwa Forest Reserve, Tabora, Tanzania: A process in the making. In: VIRTANEN, P.and NUMMELIN, M. (ed.)Forests, chiefs and peasants in Africa: Local management of natural resources in Tanzania, Zimbabwe and Mozambique. University of Joensuu, Finland. Silva Carelica 34:141-58.

KAYAMBAZINTHU, D., MATOSE,F., KAJEMBE, G. and NEMARUNDWE, N. 2003. Institutional arrangements governing natural resource management of the miombo woodland. In: KOWERO G., CAMPBELL B.M. and SUMAILA U.R. (ed.)Policies and Governance Structures in Woodlands of Southern Africa. Centre for International Forestry Research, Indonesia.

KELLERT, S.R., MEHTA, J.N., EBBIN, S.A. and LICHTENFELD, L.L. 2000. Community natural resource management: promise, rhetoric, and reality. Society and Natural Resources: An International Journal 13: 705-715, DOI: 10.1080/089419200750035575

KEMP-BENEDICT, E., BHARWANI, S., DE LAROSA, E., KRITTASUDTHACHEEWA C., and MATIN N. 2009. Assessing water-related poverty using the sustainable livelihoods framework. Stockholm Institute for Environment, Working Paper.

LOCKWOOD, M., DAVIDSON, J., CURTIS, A., STRATFORD, E. and GRIFFITH, R. 1999. Multi-level environmental governance: lessons from Australian natural resource management. Australian Geographer 40 (2): 169-186, DOI: 10.1080/00049180902964926

LOCKWOOD, M., DAVIDSON, J., CURTIS, A., STRATFORD, E. and GRIFFITH, R. 2010. Governance Principles for Natural Resource Management. Society \& Natural Resources: An International Journal 23 (10): 986-1001, DOI: 10.1080/08941920802178214.

MAROTHIA, D. 2003. Institutions for common pool resources. In: MRUTHYUNJAYA, S., P. JOSHI AND R.SAXENA (ed.)Institutional change in Indian agriculture. Pp. 61-81. Delhi: Chandu Press. 
MAUAMBETA, D., MWALUKOMO, H. and KAFAKOMA, R. 2007. Community based natural resources management in Malawi: The case of Bwanje environmental development organization (BERDO) in Ntcheu District, Malawi and Kam'mwamba sustainable management of indigenous forests (SMIF) Project, in Mwanza/Neno Districts. Southern African Natural Resources Management(NRM) Initiatives and their Impact on Poverty and Governance. Washington, DC, International Resources Group.

MUMBA, R.2003.Examination of factors affecting sustainable management of forest resources by local communities in Traditional Authorities Kunthembwe and Somba, Blantyre district: A case study of the Blantyre City Fuelwood Project (BCFP). Unpublished MSc thesis, Faculty of Environmental Science, University of Malawi.

OSTROM, E.1990. Governing the commons: the evolution of institutions for collective action. Cambridge. University Press. Cambridge.

OSTROM, E. 1999. Institutional rational choice: An assessment of the institutional analysis and development framework. In: SABATIER, P.A. (ed.)Theories of the Policy Process. 71pp. Westview Press. Boulder, Colorado.

OSTROM, E. 2011. Background on the Institutional Analysis and Development Framework. The Policy Studies Journal 39(1): 7-27.

OSTROM, E., GARDNER, R. and WALKER, J. 1994. Rules, games, and common-pool resources. The University of Michigan Press. Ann Arbor. 392pp.

OWUBAH, C., LE MASTER, D. BOWKER J. and LEE, J. 2001. Forest tenure systems and sustainable forest management. Forest Ecology and Management 149: 253-264.

PALINKAS,L.A., HORWITZ, S.M., GREEN, C.A., WISDOM, J.P., DUAN, N. and HOAGWOOD, K. 2013. Purposeful Sampling for Qualitative Data Collection and Analysis in Mixed Method Implementation Research. Administration and Policy in Mental Health. DOI 10.1007/s10488-013-0528-y

PALYS, F. 2008. Purposive sampling. In: GIVEN, L.M. (ed.) (2008). The Sage Encyclopedia of Qualitative Research Methods. Sage: Thousand Oaks, CA, Vol.2, pp.697-698.

PAUDEL, N.S., MONTERROSO, I. and CRONKLETON, P. 2010. Community networks, collective action and forest management benefits. In Forest for people: community rights and forest tenure reform. London, Washington. Earthscan

PRETTY, J. 2003. Social Capital and the Collective Management of Resources. Science 302 (5652):1912-1914.

REGMI, B., ALBANO, A. and KUMAR, C. 2008. Improving the livelihoods of the poor and marginalized in Nepal through leasehold forestry: A review of institutional constraints and opportunities. Kaski, Nepal, Local Initiatives for Biodiversity, Research and Development (LI-BIRD).

RIBOT, J.C. 2003. Democratic decentralization of natural resources: Institutional choice and discretionary power transfers in sub-Saharan Africa. Public Administration and Development 23: 53-65.

RUSSELL, A.J.M., DOBSON, T. and WILSON, J.G.M.2008. Fisheries management in Malawi: a patchwork of traditional, modern, and post-modern regimes unfolds. American Fisheries Society Symposium 62.

SCHEAFFER, R.L., MENDENHALL III, W., OTT, R.L. and GEROW, K., 2012. Elementary Survey Sampling. Seventh Edition. Brooks/Cloe, Cengage Learning. Canada. 480pp.

SCHERR, S.J.J., AMORNSANGUASIN, M.A.C., JAVIER, D., GARRITY, S. and SUNITO, S.Ir. 2001. Local organization in natural resource management in the uplands of South East 
Asia: policy context and institutional landscape. Paper presented at the SANREM conference on "Sustaining upland development in Southeast Asia: issues, tools and institutions for local natural resource management”, 28-30 May 2001, Makati City, Philippines.

SCHRECKENBERG K., LUTTRELL C. and MOSS C. 2006. Forest Policy and Environment Programme: Grey Literature Participatory Forest Management: an overview. World Development.

SHACKLETON, S., CAMPBELL, B., WOLLENBERG, E. and EDMUNDS, D. 2002. Devolution and community-based natural resource management: creating space for local people to participate and benefit? ODI Natural Resource Perspectives number 76.

SHRESTHA, K.K. and MCKANUS, P. 2006. Collective action of local communities in forest conservation and utilization: Critical reflections from Nepalese Community Forestry. IUFRO 3.08 Small Scale Forestry Conference, Dublin: COFORD.

STERN, P., DIETZ, T., DOLŠAK, N., OSTROM, E. and STONICH, S. 2002. Knowledge and questions after 15 years of research. In: National Resource Council (ed.)The drama of the commons. Pp. 445-489. Washington, DC: National Academy Press.

SURI, H. 2011. 'Purposeful Sampling in Qualitative Research Synthesis', Qualitative Research Journal 11(2): 63-75. DOI 10.3316/QRJ1102063

SWALLOW, B.M. and BROMLEY, D. 1995. Institutions, Governance, and Incentives in Common Property Regimes for African Rangelands. Environment and Resource Economics 6 (2): 99-118.

SYMAJGL, A. LEITCH, A. and LYNAM, T. (2009). Outback Institutions: An application of the Institutional Analysis and Development (IAD) framework to four case studies in Australia's outback. CRC Report 31

THIN, N. and VAN GARDINGEN, P. 2004. Participatory Forestry: Sharable Lessons for better Management of Commons. Forests, Trees and Livelihoods 14:229-242.

TONGCO, MA. D. C. 2007. Purposive sampling as a tool for informant selection. Ethnobotany Research and Applications 5: 147-158

TURYAHABWE, N., GELDENHUYS, C. J., WATTS, S. and BANANA. A.Y. 2006. Technical and institutional capacity in local organizations to manage decentralized forest resources in Uganda. The Southern African Forestry Journal 208 (1):63-78, DOI: $10.2989 / 10295920609505263$

WADE, R. 1998. The management of irrigation systems: How to evoke trust and avoid prisoners' dilemma. World Development 16 (4): 489-500

WILY, L.A. 2001. Forest Management and Democracy in East and Southern Africa : Lessons from Tanzania. Gatekeeper Series 95. International Institute for Environment and Development.

WOLLENBERG, E., CAMPBELL, B., SHACKLETON, S., EDMUNDS, D., and SHANLEY, P.

2004. Collective action and property rights for sustainable development: Collaborative management of forests. Focus 11. Brief 8 of 16. IFPRI and CAPRi.

YAMI, M., VOGL, C. and HAUSER, M. 2009. Comparing the effectiveness of informal and formal institutions in sustainable common pool resources management in Sub-Saharan Africa. Conservation and Society 7(3): 153-164. 
ZULU, L. 2008. Community forest management in southern Malawi: solution or part of the problem? Society and Natural Resources: An International Journal 21 (8): 687703.http://dx.doi.org/10.1080/08941920802039242

ZULU, L.C., 2009.Politics of scale and community-based forest management in southern Malawi. Geoforum 40: 686-699.

ZULU, L.C. 2012. Neoliberalization, decentralization and community-based natural resources management in Malawi: The first sixteen years and looking ahead. Progress in Development Studies 12 (2/3): 193 -212. DOI: 10.1177/146499341101200307

ZULU, L. 2013. Bringing people back into protected forests in developing countries: Insights from co-management in Malawi. Sustainability 5: 1917-1943. DOI: 10.3390/su5051917. 